Australian Longitudinal Study on Women's Health. Unpublished data, 1999.

8. Byles JE, Mishra G, Schofield M. Hysterectomy among women in Australia: an issue of equity and access in health care. Unpublished data, 1999.

9. Brown WJ, Dobson AJ, Mishra G. What is a healthy weight range for middle-aged women? Int J Obesity 1998; 22: 520528 .
10. Young AF, Byles JE, Dobson AJ. Women's satisfaction with general practice consultations. Med J Aust 1998; 168: 386389.

11. Pollock SE, Duffy ME. The Health-related Hardiness Scale: development and psychometric analysis. Nursing Research 1990; 39(4): 218-222. F

\title{
IMPROVING THE HEALTH AND LIFE CHANCES OF WOMEN IN DISADVANTAGED COMMUNITIES
}

\section{Elizabeth Harris and Elizabeth Comino}

Centre for Health Equity Training Research and Evaluation

\section{Lis Young and Angela Berthelson}

Macarthur Health Outcomes Unit

South Western Sydney Area Health Service

Health and opportunities for health are not equally distributed in our community; for most measures of disease the least advantaged have almost a doubling of risk compared to the most advantaged. While the health differentials between women are often narrower than between men, ${ }^{1}$ when examining mortality and morbidity by any measure of social class (such as education, employment status, or place of residence) it is the similarities between men and women within each socioeconomic group that is more striking than the differences between genders. ${ }^{2}$

There are socially-determined differences in the life experiences and circumstances between men and women: women are more likely than men to have lower incomes, have left school early, head sole parent families and be in marginal employment. ${ }^{3}$ There are broad social and economic forces that have profound influences on the health of those who are most disadvantaged that are independent of their gender. Those interested in women's health therefore need to be concerned with the significant differences in health and opportunities for health between groups of women along the social gradient. This article describes studies that show that where people live has a strong and independent influence in their health outcomes. ${ }^{4,5}$ In NSW there is growing interest in understanding how government can strengthen disadvantaged communities and this article suggests ways of achieving this.

\section{PLACE OF RESIDENCE AND HEALTH}

The Renew and Paisley Study of cardiovascular risk factors and mortality, which included approximately 7,000 men and 8,000 women, found that individually-assigned (for example: personal income, employment status) and areabased (for example: median income for an area, unemployment rates) socio-economic indicators were independently associated with several important health outcomes. ${ }^{6}$ Put simply, poor people living in poor areas had worse health outcomes than poor people living in wealthy areas. The authors concluded that action aimed

\section{TABLE 1}

\section{SELF -REPORTED HEALTH STATUS BY SOCIO-ECONOMIC DISADVANTAGE OF AREA}

Odds ratio adjusted for age, family income, employment status and other socio-economic factors, Australians aged 25-64 years, 1989-90. The 1st Quintile represents the least disadvantaged and the 5th Quintile the most disadvantaged areas.

\begin{tabular}{|llllll|}
\hline $\begin{array}{l}\text { Health Status Indicator/ } \\
\text { Socioeconomic Area } \\
\text { for Women }\end{array}$ & Age & $\begin{array}{l}\text { Odds Ratio Adjusted for } \\
\text { (and) } \\
\text { Income }\end{array}$ & $\begin{array}{l}\text { (and) } \\
\text { Employment } \\
\text { Status }\end{array}$ & $\begin{array}{l}\text { (and) } \\
\text { Risk } \\
\text { Factors }\end{array}$ & $\begin{array}{l}\text { (and) } \\
\text { Other } \\
\text { Factors }\end{array}$ \\
\hline $\begin{array}{l}\text { Fair/Poor Health } \\
\text { 1st and 2nd Quintile }\end{array}$ & 1.00 & 1.00 & 1.00 & 1.00 & 1.00 \\
3rd and 4th Quintile & $1.43^{* * *}$ & $1.29^{* * *}$ & $1.29^{* * *}$ & $1.22^{* * *}$ & $1.20^{* *}$ \\
5th Quintile & $1.64^{* * *}$ & $1.44^{* *}$ & $1.43^{* * *}$ & $1.36^{* *}$ & $1.27^{* * *}$ \\
\hline
\end{tabular}

Adapted from Mathers. ${ }^{1}$

(a) Other socio-economic factors: education, metropolitan/non-metropolitan location, country of birth, period of residence, language spoken (refer to Appendix B in Mathers for detail)

${ }^{*} \mathrm{p}<0.05,{ }^{* *} \mathrm{p}<0.01,{ }^{* *} \mathrm{p}<0.001$ 
at reducing socio-economic inequality needs to focus on the areas where people live as well as the characteristics of the people who live in these areas.

In Australia a social gradient has been found when looking at the relationship between self-reported health and place of residence. ${ }^{1}$ (See Table 1) Women living in the most disadvantaged area were 64 per cent more likely to report fair or poor health than those from more advantaged areas. Twenty-one per cent of this difference could be explained by income and employment status, seven per cent by risk factors (such as smoking), and nine per cent by other socioeconomic factors (such as country of birth, education level). This left 27 per cent of the difference unexplained.

The findings of a household survey conducted in a socially-disadvantaged community of 3,000 people in outer Sydney in 1997 provides a useful starting point for thinking about the issues within disadvantaged communities that may affect health. ${ }^{7}$ The survey area was recently identified as one of the 30 most disadvantaged communities in NSW. ${ }^{8}$ The survey was completed by 78 per cent of the 354 households where someone was found at home who was able to complete the survey (15 households were excluded because of language difficulties). This may represent a biased sample, as no one was found home in about half the households and those with language difficulties were excluded.

Findings that are presented here relate to the local environment, feelings of safety and connectedness. When asked to identify good and bad things about living in the survey area, seven per cent of respondents had three or more good things to say compared to more than half (51 per cent) who reported three or more bad things. (See Table 2 for the most common issues identified). Thirty per cent

\section{TABLE 2}

\section{RESPONDENTS PERCEPTIONS OF THE GOOD AND} BAD THINGS ABOUT LIVING IN THE STUDY AREA

\section{Four most commonly mentioned good things about living} in the study area

- Good neighbours and living near family and friends

- Schools, shops, churches and other services in close proximity

- Having a house which provided shelter, some independence and stability

- The country feeling with lots of trees, clean air and birds

Four most commonly mentioned bad things about living

in the study area

- Crime and vandalism

- Drug and alcohol problems, especially drinking and drug use in public places

- Poor local infrastructure such as no butcher or fruit shop, only one public telephone, refusal by fast food and other services to deliver in the area

- Houses and open spaces poorly designed and maintained of participants did not report any good things, whereas only seven per cent did not report any bad things. When asked the question: 'How attractive or pleasant do you think it is to walk around the streets during the day', 43 per cent of the survey area residents found it very pleasant, or pleasant compared to 86 per cent of those interviewed in the Statewide Health Promotion Survey. ${ }^{7,8}$ Thirty-three percent of survey area residents reported they were worried or extremely worried about leaving their house in case it was burgled while they were out.

Three questions were asked about feelings of connectedness with the local area. (Table 3) The responses of women with children under five years in the survey area were compared to the findings of a random telephone survey of mothers with young children in the local government area in which the disadvantaged community is located. ${ }^{9}$ Forty-eight percent of mothers in the survey area compared to 25 per cent in the phone survey reported they did not have much interest at all in what goes on in their area. Thirty-one per cent said they 'did not feel at home' compared to six per cent in the phone survey. And 60 per cent in the survey area 'would not be sorry to leave' compared to 24 per cent of the phone survey.

These figures paint a powerful picture of many people who are already socially disadvantaged living in areas where they feel vulnerable and disconnected. However, even within this disadvantaged community there are still many people who are interested in what goes on, who do feel safe and who can identify good things about the area in which they live. In any intervention to improve the health of this community it will be important to recognise these strengths as well as address identified problems or difficulties.

\section{STRENGTHENING COMMUNITIES}

In NSW there is growing interest in understanding how government can strengthen disadvantaged communities. For example, the Strengthening Communities Unit has been established within the Premier's Department and this unit has established a Community Builders Web site to link activities around the state (see site at www.comunitybuilders.nsw.gov.au); and within the health system community health workers and Divisions of General Practice are working to address the needs of disadvantaged communities. The following suggests ways through which we can build on these initiatives and ensure they address needs of women who live and spend most of their time in these communities:

\section{Develop networks/information flow across health services.}

It is important to develop networks and flow of information between those within the health system who have an interest in working in disadvantaged communities to provide support, training, and models of best practice. 


\section{TABLE 3}

\section{COMPARISONS OF PERCENTAGES OF BELONGING TOTHE NEIGHBOURHOOD INTHE SURVEY AREA}

COMPAREDTOTHE MACARTHUR INFANT ANDTODDLER [TELEPHONE] SURVEY.

\begin{tabular}{lcc}
\hline & $\begin{array}{c}\text { Study Area mothers withchildren } \\
\text { under } \mathbf{5}(\mathbf{n = 1 7 7 )}\end{array}$ & $\begin{array}{c}\text { Local Government Infant/Toddler Health } \\
\text { StatusTelephone Survey }(\mathbf{n = 1 , 0 2 5})\end{array}$ \\
\hline $\begin{array}{l}\text { Much interest in what goes on } \\
\text { in your neighbourhood }\end{array}$ & & 31.7 \\
Yes, a lot & 22.6 & 42.0 \\
Yes, a bit & 28.8 & 18.6 \\
No, not much & 21.5 & 6.7 \\
No, not at all & 26.6 & 75.2 \\
Feel at home in your neighbourhood & & 17.7 \\
Yes, a lot & 36.7 & 3.5 \\
Yes, a bit & 32.2 & 2.6 \\
No, not much & 9.0 & \\
No, not at all & 22.0 & 48.8 \\
Sorry to leave your neighbourhood & & 26.4 \\
Yes, a lot & 19.8 & 12.9 \\
Yes, a bit & 19.8 & 10.9 \\
No, not much & 11.3 & \\
No, not at all & 48.6 & \\
& & \\
\hline
\end{tabular}

\section{Fund and encourage evaluation of interventions.}

There are few interventions that have been evaluated despite increasing levels of interest and activity. Without systematic evaluation it is not possible to identify where intervention is most effective and where new approaches are required.

\section{Partnership with other departments and organisational structures.}

The areas where there are significant health problems are also areas where there are poor educational outcomes, increased levels of violence and poor housing. Government departments working together provide the best chance for achieving a critical mass of commitment and resources necessary to make a difference.

\section{Work with those living in disadvantaged} communities rather than for them.

Experience with the most marginalised groups in our society shows that real gains are only made when mainstream services work with those most affected to achieve a change.

\section{CONCLUSION}

Anyone who has worked in these disadvantaged communities knows that women are the driving forces for change. The challenge for women's health is to identify the areas where they should work, such as increasing breast screening, addressing social isolation, domestic violence, fear of robbery, women's or community issues. Any decision must be guided by those most directly involved with the problem to ensure that interventions have relevance to the lives of these women who need our support the most.

\section{REFERENCES}

1. Mathers C. Health Monitoring Series 1: Health differentials among adult Australians aged 25-64 years. Canberra: Australian Institute of Health and Welfare, 1994.

2. NSW Department of Health. Chief Health Officer's Report. Sydney: NSW Department of Health, 1996.

3. Australian Bureau of Statistics. Australian Social Trends. Canberra: Australian Bureau of Statistics, 1999.

4. Kawachi I, Kennedy BP, Glass R. Social capital and selfrated health: a contextual analysis. Am J Public Health 1999;89(8):1187-93.

5. Lynch JW, Kaplan GA, Panuk ER et al. Income inequlaity and mortality in metropolitan areas of the United States. Am J Public Health 1998;88(7):1074-80.

6. Smith GD, Hart C, Watt G et al. Individual social class, areabased deprivation, and cardiovascular disease risk factors: the Renfrew and Paisley Study. J Epidemiol Community Health 1998;52(6): 399-405.

7. Waldon S, Young L, Harris E, et al. Resident Household Survey. Sydney: Macathur Health Outcomes Unit and the Centre for Health Equity Training Research and Evaluation, 1997. Unpublished but available on request.

8. National Centre for Health Promotion, NSW Department of Health. NSW Health Promotion Survey 1994. Sydney: NSW Department of Health, 1995. State Health Publication No. HP 950145.

9. Young L and Berthelson A. Macarthur Infant and Toddler Survey. Macarthur Health Outcomes Unit, 1997. Unpublished report. $\boldsymbol{F}$ 